\title{
EKPHRASIS AND MODERNISM: A STUDY OF TWO POEMS BY WALLACE STEVENS AND WILLIAM CARLOS WILLIAMS ${ }^{12}$
}

\author{
Natalia Carbajosa, Universidad Politécnica de Cartagena \\ Email: natalia.carbajosa@rec.upct.es
}

\begin{abstract}
Resumen: Se suele definir la écfrasis como la descripción o comentario literario de una obra de arte, real o imaginaria. En este artículo se partirá de la écfrasis y de su relación con la teoría de los signos de Peirce en el análisis de dos poemas de los modernistas norteamericanos Wallace Stevens y William Carlos Williams. El objetivo es estudiar cómo opera esta figura en un período de aguda consciencia de la relación verbal-visual, así como extraer algunas conclusiones sobre el modo en que cada poema en particular explora dicha relación.
\end{abstract}

Palabras clave: écfrasis, poesía modernista, relación verbal-visual, teoría de los signos, la vanguardia.

\section{Titulo en español:}

Abstract: Ekphrasis is commonly known as the literary description or commentary of a real or imaginary work of art. In this article, ekphrasis and its relation with Peirce's theory of signs will be considered for the analysis of two poems written by two American Modernist poets, Wallace Stevens and William Carlos Williams. The aim of this study is to analyze the role of ekphrasis in a period of acute consciousness of the visual-verbal interrelationship, as well as to extract some conclusions concerning the particular way in which both poems explore such a relation.

Keywords: ekphrasis, Modernist poetry, visual-verbal interrelationship, theory of signs, the avant-garde.

One of the main tools used in inter-artistic comparison of poetry and the visual arts -in other words, the realization of the Horatian adage $u$ t pictura poesis-is ekphrasis. The term comes from the Greek ekphrazein (to express) and it refers to the attempt to imitate with words a real or imaginary object from the visual arts, normally a painting or a sculpture. The beginnings of ekphrasis can be found in the ancient Greek technopaegnia, originally poem-objects, that is, real objects with a literary description, gloss or spell engraved on them. Gradually, the technopaegnia were transformed into primitive calligrammes. This simply means that they reproduced the shape of an absent object. The first work of poetic ekphrasis identified as such is Homer's description of Achilles' imaginary shield in the Iliad.

\footnotetext{
Date of reception: 26 March 2012

Date of acceptance: 21 November 2012

2 Research for this study was funded by a grant from The Regional Ministry of Culture of the Regional Autonomous Government of Castile \& Leon (ref. number SA012A10-1).
} 
image, such as Keats' celebrated "Ode on a Grecian Urn.” Actually, ekphrasis has been constantly employed by poets in order to explore the complexities of the visual-verbal interrelationship.

Furthermore, twentieth-century Anglo-American Modernist poetry has been repeatedly described as one of the literary periods during which the ut pictura poesis metaphor was most widely and fruitfully exerted. In modern times, Apollinaire's calligrammes inaugurated the concept of visual poetry, a concept that revolutionized the way of approaching a poem: "By calling attention to its physical premises, visual poetry insists on the autonomy of the text, on its integrity as an expressive form" (Bohn 1986: 67). Soon, avant-garde movements like Pound's Imagism and Vorticism began to highlight the new relation existing between poetry and the visual arts. Concretely, poetry started to draw on those avant-garde currents that abandoned figurative painting for the paths of abstraction: "The poetry of the modernist avant-garde shows a filial relationship with abstract art, especially with Cubist painting" (Patea 2011: 272).

Within the Modernist movement, some poets, as is the case of Wallace Stevens and William Carlos Williams, acknowledged the importance of modern art as a fundamental influence in their poetry. They were assiduous gallery-goers, who maintained relations with artists of the New York pictorial and photographic avant-garde and who wrote numerous essays and poems on art works. Thus, they illustrate a poetic orientation which is considered characteristic of American Modernism: a trend which is also the hallmark of the Modernist expatriates Eliot and Pound, who also admit the importance of modern art for their own poetry.

Some of Stevens' book titles, such as Harmonium (1923), Ideas of Order (1935) or Parts of the World (1942), reveal the poet's constant concern with aesthetic order: an order that he locates primarily in the individual, in the eye that sees and perceives. Stevens resorts to art in order to confront the way in which he captures reality. He also makes ekphrastic commentaries of real or imaginary pictures. In contrast, Williams is considered to resort to ekphrasis more openly than Stevens. In fact, Williams seems to be more concerned with providing a personal interpretation of the ut pictura poesis. His most obvious ekphrastic collection of poems is Pictures from Brueghel (1962), yet throughout his writings he seems convinced of art's preeminence over language and of its capacity to communicate effectively. Actually, he seems to be constantly longing for ways of transferring meaning from visual art into language: "Williams disliked the secondary intensity of language used as a symbol system. Modern painting was unmediated, sensuous. His great achievement was to bring some of its qualities into poetry" (Costello 1979: 1).

In both cases, the poets' recourse to ekphrasis can be read through the theory of signs formulated by Charles Sanders Peirce (1974). The classical semiotic differences that Peirce highlights among the three types of signs, namely icons, indexes and symbols, are relevant insofar as the relation which the signifier establishes with the referent differs in each case. The icon establishes a relation of resemblance (in figurative painting and photography), the index operates by contiguity (smoke denotes the proximity of fire) and the symbol has a completely arbitrary or conventional relation to its referent, as is the case, for example, of the qualities attributed to colors. According to this division, language is primarily symbolic, with the exception of certain indexical elements such as the demonstratives, the personal 
pronouns and the adverbs of location and time, which place the discourse in the "here" and "now" of the communicative context. The indexical elements of language constitute fundamental pieces for a pragmatic analysis of language, that is, the study of language in use (Hanks 2000: 124-126).

Obviously, reality denies such a clear-cut catalogue of signs. Despite the general agreement on the essentially symbolic nature of the linguistic sign, Jakobson argues that language has many properties common to different sign systems, which he calls "pansemiotic features" (1960: 351). Given that language is primarily symbolic and that painting was mainly iconic, the concept of "visual poetry" and the literary experiments of the avant-garde illustrate the iconic nature of poetic language. A case in point is Pound's and Fenollosa's works with Chinese ideograms. As a matter of fact, Modernist poets try to prove that "poetic language is constituted of iconic relations" (Steiner 1982: 24), rather than of exclusively symbolic ones.

This view of the nature of poetic language is conducive to the Modernist notion of poetry as a time "when the entire poem or text is regarded as an image or "verbal icon"" (Mitchell 1986: 25). Modernist poetry rose, as we know, exactly at the time when art abandoned figurative certainties for the exploration of abstraction. In other words, Modernist poetry bloomed exactly when art gave up the mimetic representation of reality in order to constitute an object, an artifact, a reality in itself. Both processes, the abandonment of figurative representation by painting and poetry's approach of iconicity, constitute a remarkable semiotic shift in twentieth-century aesthetic perception, a shift that, to this day, marks the greatest difference between Postmodernism and the aesthetic systems prior to the Modernist avant-garde.

The path is open, therefore, for questioning and expanding the classical definition of ekphrasis, summarized as "the verbal representation of visual representation" (Heffernan 1993: 3). And it must be so, since both representations of the visual and the verbal -in other words, the capacity of representing reality by means of art- are concepts which have undergone significant changes in the last century. The poets who were immersed in the first stage of this major change of perspective give evidence in their compositions not of having reached ultimate conclusions, but of the dynamic implications of the whole process. Thus, in the poems of Stevens and Williams, ekphrasis becomes mostly a tool for experimenting with language, art and the perception of reality, even if the final result is only partially ekphrastic. The poems below will be analyzed from the perspective of these theoretical premises.

Stevens's typical example of ekphrastic poetry or, rather, of a parody of classical ekphrasis, is "Anecdote of a Jar" (Mitchell 1994: 19-22). Likewise, his famous piece "Thirteen Ways of Looking at a Blackbird" has been considered by critics "The best known early American Cubist poem" (Jenkins 2000: 143), as it illustrates the poet's involvement with this artistic trend. His 1942 poem "Study of Two Pears" is neither properly ekphrastic nor Cubist-Stevens showed his explicit interest in Cubism through a wide range of articles and poems other than this poem- but it acquires both literary and visual qualities. I have chosen it, precisely, for the subtle indirectness with which the poet approaches both ekphrasis and Cubism and the imaginative relations he establishes in it between sound and color: 
Opusculum paedagogum.

The pears are not viols,

Nudes or bottles.

They resemble nothing else.

II

They are yellow forms

Composed of curves

Bulging toward the base.

They are touched red.

III

They are not flat surfaces

Having curved outlines.

They are round

Tapering toward the top.

IV

In the way they are modeled

There are bits of blue.

A hard dry leaf hangs

From the stem.

$\mathrm{V}$

The yellow glistens.

It glistens with various yellows,

Citrons, oranges and greens

Flowering over the skin.

VI

The shadows of the pears

Are blobs on the green cloth.

The pears are not seen

As the observer wills.

The poem is apparently simple in its structure but purposefully misleading, as we can observe from its title and the very first line. It seems logical to understand that the term "study" refers to a painting, but it may also be a reference to a close observation of two real pears. Whatever option we choose is problematic in relation to the title and the first line of the poem, and it has been identified as such by scholars:

I take it that the "study" refers to a painting, which in turn affords us an opportunity to study how we go about seeing in a vital way. Yet the very framework of the study may eventually prove as limiting and self-mocking as the Latin pedagogy that sets the scene (Altieri 1985: 97).

The "Opusculum paedagogum," in fact, makes reference to the scarce importance of this teaching. The poem, therefore, starts as an understatement, and it keeps this dismissive tone both by means of the apparent simplicity of verse and stanza and through the insistence -both at the beginning, in the middle and at the end of the composition- on what the pears "are not." 
The poem is not ekphrastic, yet it behaves as if it were: it resembles the description of a Cubist painting where recognizable shapes ("viols", "nudes", "bottles" or "flat surfaces") and the rational workings of the mind ("as the observer wills") are discarded. Instead, we find only a fragmented structure of different perceptions concerning the outline and composition of the two pears ("In the way they are modeled"), based on an eclectic texture of color, geometric forms and an illusion of movement. Form is, indeed, revealed by color ("yellow", "red", "blue", "green") and color appears intrinsically related to shape ("forms", "curves", "round", "modeled"). This reminds us of Cézanne's technique of composition, where each color stroke relates the parts of the picture to the environment, instead of just filling in lines previously drawn with a pencil. But color obviously cannot appear by means of brush strokes in Stevens's piece, because his communicative medium is language, not painting. An alternative technique, available for writing, must be sought and found. And at this phase of the analysis we observe that color appears to be embodied in sound, in an equation that has been identified within the influence of Symbolism as a key poetic movement prior to Modernism: "The Symbolist legacy is present in the attention he [Stevens] paid to color and sound imagery" (García Lorenzo 2005: 76). When we bear this color-sound equation in mind, we can truly comprehend how Stevens's short study, neither an ekphrastic poem nor a Cubist collage, makes both present.

In his Un Coup de dés (1897), Mallarmé affirmed the aesthetic autonomy of the signifier. We can safely argue, consequently, that visual poetry originated in Symbolist aesthetics. Mallarmé also introduced a theory of color-vowel correlation which sought to match the symbolic values of colors with corresponding sounds. Subsequently, the comparison of color and sound in relation to poetry and the visual arts has given way to numerous structuralist studies that seek the minimal unit of painting, something comparable to phonemes in language. Steiner, for example, refers to Dora Vallier's theory about the similarities "between color relations and vowel relations, on the one hand, and achromatic and consonantal relations on the other." According to this theory, "the more precise the correlation, the more intense the iconicity" (Steiner 1982: 30). Thus, language attains iconic properties at a phonemic level. The preeminence of structuralism and its focus on minimal units of meaning in any signification system is no longer a priority in linguistic research. However, the structuralist equivalences between sound and color demonstrate that there has been a shared concern since the Symbolist period.

It is hard to say whether at the time he wrote his poem Stevens had in mind a specific theory about the correlation of sound and color. Nevertheless, the relation he establishes between both elements is undeniable. References to color appear in the poem related to verbs and prepositions of movement ("bulging toward", "touched", "tapering toward", "flowering over") or to verbs that express some nuances of light ("glistens", a verb which appears twice and in two consecutive lines). Through the use of these verbs and prepositions, the poet seems to surpass the static nature - static because it is subjected to a visual model- of his picture with words. He is building, in fact, a "verbal icon", a language object that is trying to impersonate a visual object. Stevens is, therefore, achieving a desirable quality 
not in painting -the vividness of a scene, also known as enargeia ${ }^{2}$ - but in a literary work. Furthermore, he is pointing to this quality basically through alliteration -that is, at the phonemic level of the language-, in most cases at the beginning and end of each short line ("composing" and "curving", "bulging" and "base", "tapering" and "top", "bits" of "blue", "blobs" and "cloth"). The apparent simplicity of verse and stanza thus acquires unexpected levels of complexity.

The phonemic qualities of color enhanced the visual-verbal interrelationship at the beginning of the avant-garde. Furthermore, the rhetorical figure which belongs to the domain of semantics, known as diaphora, will enable us to transfer some stylistic strategies from the semantic to the phonemic level. The diaphora refers to the stylistic effect, in language, which is produced when a word or an expression is repeated within the same line, as when the Shakespearean heroine Viola utters "I am not what I am" in Twelfth Night (Act III, scene I). The second repetition of the expression is always semantically charged, that is, it introduces new connotations to the first one. This is especially noticeable if, as in this example, the repeated term denies the first statement.

When we transfer this figure from the semantic to the phonemic level, it is sound, not meaning, which becomes strongly emphasized by this repetition. What is more, sound conveys meaning, in the same way in which painters like Van Gogh or Matisse proved that color could convey character and emotions in modern painting. In "Study of Two Pears," for example, the phoneme /k/ in "curves" adds connotations ${ }^{3}$ to the same phoneme in "composed", and the same occurs with /b/ in "base" after "bulging", /t/ in "top" after "tapering" and "toward", and so on. Accordingly, the poem can be said to communicate more than the meaning of each word because in structural terms it transforms phonemes into minimal units of significance. Stevens has defied the mere use of the word as a symbolic sign, or as the only instrument of communication available, in order to convey a "reality" that equally challenges traditional modes of perception: "The pears are not seen / as the observer wills." Moreover, to do so, the poet has made use of linguistic collage techniques, comparable to the pictorial ones, by taking semantic categories to the field of phonetics, as well as by representing color and movement -i.e. an illusion of materiality- through them.

The conclusion of this analysis partly coincides with Costello's statement that "the poem does not offer an equivalent in language to Cubist concerns and techniques, but rather a description of those concerns and techniques, a substitution rather than an apposition" (1985: 84). From a semiotic point of view, it could be argued that "Study of Two Pears" operates like one of those calligrammes of the second period of the Greek technopaegnia, which reproduced the shape of the described object in its absence. In Mitchell's words, this primitive materialization, through only words, of an absent object, may be properly called

\footnotetext{
2 Painting is static, but the figure of enargeia makes reference to the composition techniques through which a dramatic effect is sought, with characters in action or objects in movement. Enargeia became fashionable especially from the Renaissance on. Futurism and other avant-garde movements, both in painting and sculpture, seek to reach the limits of this figure, as is the case in some works by Gaudier-Brzeska, Picasso and many others.

3 I use the term "connotations" always in a phonemic, not a semantic sense. The occlusive nature of $/ \mathrm{k} /$, by means of repetition, as well as the rest of repeated sounds, are the key to an "alternative" reading of the poem, based on sound as well as on meaning.
} 
an act of "verbal conjuring" (1994: 9), and it very possibly performed a ritualistic function in ancient Greece. It is only in this regard, through the materialization of an element of reality -the two pears, or a still life showing two pears-, that "Study of Two Pears" can be considered ekphrastic or Cubist. Stevens achieves this effect not through conventional techniques of description, but through the use of simultaneous, multiple perspectives -conveyed mainly by the overlapping of sound and color in the composition- that present similarities with the techniques employed by Cubist painters.

However, the ambiguity of the whole composition -the tone, the misleading title, the deliberate simplicity of the lines- cannot be ignored. Bearing in mind the semiotic implications of the analysis on one hand and the casual tone of the poem on the other, we may consider "Study of Two Pears" to be an open and endless reflection on perception rather than a finished artifact, a reflection which neither confirms nor denies the plausibility of the ut pictura poesis metaphor, that is, of the effective possibilities of ekphrasis in the Modernist era, but which at the same time seems to be fairly confident, despite its ironic tone, of the actual communicative possibilities of language.

If in the case of Stevens' "Study of Two Pears" the ekphrastic debate may be focused on the poem's treatment of sound and color, Williams's reading of the ut pictura poesis adage in his poem "Portrait of a Lady" (1920) shows different concerns and provides different conclusions. "Portrait of a Lady" was prior to the well-known Brueghel series, and to a certain extent it anticipates the techniques developed in that collection. In relation to Williams's approach to the literary commentary of Brueghel's pictures, Steiner affirms that "Williams's understanding of the ut pictura poesis simile went beyond the metaphoric ... to the creation of structural equivalents of paintings in his poems" (1982: 73). What we find in "Portrait of a Lady" does not actually constitute a "structural equivalent" of a picture, but it offers ample scope for discussion of the limitations of language used for ekphrastic purposes. Furthermore, it leads Williams towards a path which he followed from then on, which will be explained later precisely in relation to his Brueghel series. Just as in Stevens' case, the beginning is ambiguous and overtly ironical:

\author{
Your thighs are appletrees \\ whose blossoms touch the sky. \\ Which sky? The sky \\ where Watteau hung a lady's \\ slipper. Your knees \\ are a sudden breeze-or \\ a gust of snow. Agh! what \\ sort of man was Fragonard? \\ -as if that answered \\ anything. Ah, yes-below \\ the knees, since the tune \\ drops that way, it is \\ one of those summer days, \\ the tall grass of your ankles \\ flickers upon the shore- \\ which shore?-
}


the sand clings to my lips-

Which shore?

Agh, petals maybe. How

should I know?

Which shore? Which shore?

I said petals from an appletree.

Despite the title and the poem's involvement with painting, this may and may not be a case of ekphrasis, although for different reasons from those discussed in Stevens' poem. The allusions to a famous eighteenth-century rococo painting of clear erotic content and to the two best-known painters of this period, Watteau and Fragonard, do not help much, as the paintings and artists alluded to are, deliberately or unintentionally, mixed. Actually, the picture attributed to Watteau, "The Swing," with the lady's slipper pointing at the sky, was in fact painted by Fragonard in 1767, although Watteau had painted a similar scene in 1712. With its mixture of innocent play and adult observation, this pastoral scene has always been a popular theme in painting. In contrast, Williams' use of a cliché catalogue of erotic metaphors, some of them justifiable only in regard to the rhyme ("knees" and "breeze") or capriciously interchanged ("Your knees / are a sudden breeze - or a gust of snow"), is meant to reveal the voice of an unskilled poet, and thus establishes a clear distance with the author of the composition.

As for the characters that appear in the poem, there is a certain degree of ambiguity in this domain as well. Mitchell suggests that this is "an ekphrastic poem that may be an address to a woman who is compared to a picture, or a woman in a picture" (1994: 23). He also points out that the interrupting voice that frustrates any attempt from the poet to continue with his catalogue of metaphors, i.e. the one who poses constant questions in search of clearer meaning, may be "that of the addressed woman, or of the poet's unconscious, or of the poet's implied reader" (24). In any case, it seems quite evident that the interrupting voice is that of a woman who is resisting her being used by the poet as a pretext for a poem. She claims attention for herself as a subject, rather than as an object of desire. This idea is coherent not only with Williams' awareness that throughout history male poets resort to a passive female muse. It may properly be affirmed that "women and the mixed belittlementadoration accorded them by men (included the poet)" also constitutes a persistent theme in his poetry (Baym et al. 1994: 1184). Moreover, through her annoying interruptions, the rebellious muse challenges the taken-for-granted use of the metaphor ("Which sky?" "Which shore?"), thus questioning all accepted notions about poetic language, and the capacity of language to signify poetically. It is not by chance, then, that Language Poets, who were so suspicious of metaphors, should take Williams as a model for their own poetry.

However, according to Mitchell, the poet-muse dialogue does not make the poem less ekphrastic, as ekphrasis itself implies voyeuristic contemplation of the kind the unskilled poet of "Portrait of a Lady" is so unsuccessfully trying to express. Wherever the intrusive voice comes from, it "resists the smooth, pleasurable fondling of the ekphrastic image, the sensuous contemplation of the woman's body, mediated through the familiar metaphors of fruit, blossoms, petals, wind, and sea" (1994: 24). Following Mitchell, Puglisi (2003: 15-56) is also convinced of the ekphrastic nature of "Portrait of a Lady" and its anticipating role 
in Williams' subsequent poems about paintings. She adds an interesting nuance, though, to Mitchell's analysis: Williams regarded language as a deficient system of communication in comparison with painting, and this poem seems to confirm this conception. Consequently, the poem's abrupt and exasperated conclusion, with its return to the initial line, explicitly acknowledges that the task undertaken has been frustrated (33). This abrupt ending seems all too logical after the poet's repeated irritation (“Ahg!", "How should I know?"). What is more, it gives evidence of Williams' firm belief in the linguistic silence of the work of art, which can only communicate through purely visual means. Moreover, such a particular notion of art seems in consonance with the poet's famous statement "no ideas but in things." In this way, ekphrasis becomes, in this particular example, a completely failed attempt because language seems incapable of meeting the expectations it has raised. It is, properly speaking, an example of anti-ekphrasis. This could be a more than plausible interpretation of the poem.

However, purposefully or not, in "Portrait of a Lady," Williams has also achieved an indirect effect equally indebted to the visual-verbal interrelationship. To a certain extent, the poem is emphasizing the semiotic shock that has taken place in modern art since the advent of abstract painting. With such an old-fashioned use of metaphors, the male voice in "Portrait of a Lady" is not only revealing the uselessness of such language. He may also be indirectly signaling the challenge a twentieth-century commentator must face when speaking about art in general after the major semiotic turning point that marked the advent of the avant-garde. Art scholars and curators quite often refer, for example, to the consequences of this major semiotic change for twentieth-century museum-goers. In a catalogue of the Tate Modern in London, one of the most important contemporary art centers in the world, we may read the following:

A medieval Londoner could read the symbolic iconography of saints, a lexicon of images that was instantly accessible [...] An art lover in Georgian times understood the classical fables, reading of the fauns and Dianas like notes on a score [...] A mid-Victorian gallery goer had a whole internal dictionary of romantic responses to waterfalls, Shakespearean scenes and the like [...] But a lot of what is in Tate Modern repels 'reading' in that way (Marr 2006: 13-14).

If we apply Marr's reflections to "Portrait of a Lady," we can conclude that the speaker's exasperation may come from the fact that Williams has already learned about the futility of trying to "read" a picture, that is, to render it in words like the educated citizens of the nineteenth-century could do. Man is no longer a connoisseur, nor can he be, in a world in which words for interpreting art are hard to find. Read from this perspective, the "How should I know?" of the unskilled poet in "Portrait of a Lady" reads not only as a futile reply to the woman's objection concerning his stereotyped use of metaphors, but as an equally insufficient commentary of the qualities of the picture -or pictures- on which the poem is apparently drawing for its own development. From this double point of view, the patent acceleration of the poem towards its inadequate conclusion by means of enjambment, profusion of dashes and a faster and faster exchange of questions and answers could be said, in effect, to constitute that "structural equivalent" that we denied at the beginning 
of the analysis. "Portrait of a Lady" could be equated not with Watteau or Fragonard's painting, but with the incapacity to describe in words any of those paintings. By all means, this particular attempt at ekphrasis cannot render a picture with words and, consequently, it rushes awkwardly towards its conclusion.

It is exactly with this same attitude towards the visual-verbal interrelationship that Williams, years later, dares to speak about the paintings of the sixteenth-century Flemish artist Peter Brueghel. In his book on Brueghel's paintings, he does not try to explain the pictures at all. Instead, he builds a linguistic equivalent to them, a real verbal icon in the sense that description, or attempts at description, have completely given way to substitution. William's approach to ekphrasis, his distrust of conventional ways of merely commenting or describing pictures, reaches its maximum expression in this book, and it seems to be fully in consonance with the modern ways of signification for art:

But ekphrastic poetry is not art history [...] Ekphrasis never aims simply to reproduce a work of visual art in words, so there is no point in judging ekphrastic poetry by a criterion of fidelity to the work it represents. We can much better judge it by asking what it enables us to see in the work of art, or even just to see, period (Heffernan 1993: 157).

Heffernan's final remark about what ekphrasis enables us "just to see," regardless of whether the ekhrastic poem deals with a recognizable painting or not, is the appropriate way to approach Stevens's "Study of Two Pears" or Williams's "Portrait of a Lady." In the nonsensical, careless air that the latter displays, Williams prepares the way for what would come later: he puts forward what should not be done in order to explore what should be done, in a similar way in which Stevens previously pointed out what the pears "are not" in order to make us see them from a different perspective. Williams questions thus the validity of ekphrasis as glossing, i.e. a mere verbal actualization of the ancient technopaegnia. What he seems to propose is not the composition of a poem that describes an object in absentia but, instead, the creation of another "object," the poem understood as an object itself, rather than as a substitution. Consequently, the apparent intention of "Portrait of a Lady" to make traditional courtship through traditional, metaphor-relying ekphrasis, is a failure. If poetic language is to have any relationship at all with the visual arts and become really iconic, it has to find a different way.

Paterson (1953), no less than Williams' whole poetic output, shows a constant concern with the impossibility of language to communicate, that is, to surpass the distance between the linguistic sign and reality, between words and things, or between signifiers and their referents. Yet Williams never abandoned the hope of using ekphrasis so as to overcome this gap: As Floriana Puglisi aptly affirms, Williams pursued "the total correspondence between sign and referent" in the verbal transpositions of visual works of art (2009: 591). Actually, this constant longing for a sort of prelapsarian language, for an unquestioned correlation between the linguistic sign system and the world, has been present in all periods of the history of literature. Modernism, with its explicit attempt to blur the limits of signification within arts, was obviously concerned with such longing.

One element has changed, though, in relation to previous epochs: after the avant-garde, poets and artists distrust their tools and their own capacity for perception. Their works 
reproduce, in this way, a concern for the creative process per se, together with the relations this process establishes with the referred world, that has no precedents in the history of art and literature. For the Modernists, the semiotic aspect of art and literature meant much more than idle speculation. In their time, it was agreed that "just as complex as the argument about how artistic signs signify reality is the issue of whether they in fact do signify it" (Steiner 1982: 26). Read under these considerations, "Study of Two Pears" and "Portrait of a Lady" manifestly constitute two valid examples of uncertainty: their ambivalence or lack of definition in relation to ekphrasis points directly to the ambiguous nature of representation, and constitutes a clear sign of the artistic episteme of their era.

\section{REFERENCES}

ALTIERI, C. 1985. "Why Stevens Must Be Abstract, or What Poets Can Learn From Painting." Wallace Stevens: The Poetics of Modernism. Ed. A. Gelpi. New York: Cambridge University Press. 86-118.

BAYM, et al. 1994. "William Carlos Williams." The Norton Anthology of American Literature vol. 2. New York: W.W. Norton \& Company. M1183-1185.

BOHN, W. 1986. The Aesthetics of Visual Poetry 1914-1928. Chicago \& London: Chicago University Press.

COSTELLO, B. 1979. "William Carlos Williams in a World of Painters.” Boston Review June/July Issue. 25 Sept. 2011. http://bostonreview.net/BR04.6/costello.html.

. 1985. "Effects of an Analogy: Wallace Stevens and Painting." Wallace Stevens: The Poetics of Modernism. Ed. A. Gelpi. New York: Cambridge University Press. 65-85.

GARCÍA LORENZO, M.M. 2005. American Literature after 1900. Madrid: UNED.

HANKS, W.F. 2000. “Indexicality.” Journal of Linguistic Anthropology 9 (1-2): 124126.

HEFFERNAN, J. A. W. 1993. Museum of Words: The Poetics of Ekphrasis from Homer to Ashbery. Chicago: The University of Chicago Press.

JAKOBSON, R. 1960. "Linguistics and Poetics." Style and Language. Ed. Thomas A. Sebeok. Cambridge, MA: MIT Press. 350-377.

JENKINS, L.M. 2000. Wallace Stevens: Rage for Order. Brighton: Sussex Academic Press.

MARR, A. 2006. "The Magic Box.” Tate Modern: The Handbook. London: Tate Publishing. 13-18.

MITCHELL, W. J. T. 1986. Iconology: Image, Text, Ideology. The University of Chicago Press. 
. 1994. "Ekphrasis and the Other." Picture Theory. University of Chicago Press. 27 Oct. 2011. http://www.otal.umd.edu/rc/eleced/medusa/mitchell.html.

PATEA, V. 2011. "The Poetics of the Avant-Garde: Modernist Poetry and the Visual Arts.” SPELL: Swiss Papers in English Language and Literature 26: 265-280.

PEIRCE, C.S. 1974. La ciencia de la semiótica. Buenos Aires: Nueva Visión.

PUGLISI, F. 2003. "Imagini e parole: il ritratto dell'artista nel museo poético di William Carlos Williams.” Siciliomi II. Anuario di Varie Scritture. Ed. M. ARGENTO. Catania: Prova D'autore. 15-56. . 2010. “To Die 'Incommunicado': Problems of Translation and Communication in William Carlos Williams's Paterson. ” Translating America: Importing, Translating, Misrepresenting, Mythizicing, Communicating America. Eds. M. Camboni, A. Carosso \& S. di Loreto. Torino: Otto. 587-596.

STEINER, W. 1982. The Colors of Rhetoric: Problems in the Relation between Modern Literature and Painting. Chicago: The University of Chicago Press. 


\section{Please use this identifier to cite or link to this item:}

http://hdl. handle. net/10835/2076

Full metadata record

DC Field

Value

dc.contributor.author Carbajosa, Natalia

dc.date.accessioned 2013-04-04T12: 11:54Z

dc.date.available 2013-04-04T12:11:54Z

dc.date.issued 2012

dc.identifier.issn $1578-3820$

dc.identifier.uri http://hdl.handle.net/10835/2076

dc.description.abstract Ekphrasis is commonly known as the literary

es_ES description or commentary of a real or imaginary work of art. In this article, ekphrasis and its relation with Peirce's theory of signs will be considered for the analysis of two poems written by two American Modernist poets, Wallace Stevens and William Carlos Williams. The aim of this study is to analyze the role of ekphrasis in a period of acute consciousness of the visual-verbal interrelationship, as well as to extract some conclusions concerning the particular way in which both poems explore such a relation.

dc.publisher Universidad de Almería.

dc.source Odisea : Revista de Estudios Ingleses. Número 13, es_ES Enero-Diciembre 2012

dc.subject Écfrasis

es_ES

dc.subject Poesía modernista

es ES

dc.subject Relación verbal-visual

es_ES

dc.subject Teoría de los signos

es_ES

dc.subject La vanguardia

es_ES

dc.subject Ekphrasis

es_ES

dc.subject Modernist poetry

es_ES

dc.subject Visual-verbal interrelationship

es_ES

dc.subject Theory of signs

es_ES

dc.subject The avant-garde

es_ES 
dc.title Ekphrasis and Modernism: A Study of Two Poems es_ES by Wallace Stevens and William Carlos Williams.

dc.type info: eu-repo/semantics/article es_ES dc.relation.publisherversion http://www.ual.es/odisea/Odisea13_Carbajosa.pdf es_ES dc.rights.accessRights info: eu-repo/semantics/openAccess es_ES Appears in Collections: Odisea : Revista de Estudios Ingleses. Número 13, Enero-Diciembre 2012 